\title{
Evidence of the bioaccumulation of ciguatoxins in giant clams (Tridacna maxima) exposed to Gambierdiscus spp. cells
}

\author{
Roué Mélanie ${ }^{1,{ }^{*}}$, Darius Hélène Taiana ${ }^{2}$, Picot Sandy ${ }^{1,2}$, Ung André ${ }^{2}$, Viallon Jérôme ${ }^{2}$, \\ Gaertner-Mazouni Nabila ${ }^{3}$, Sibat Manoella ${ }^{4}$, Amzil Zouher ${ }^{4}$, Chinain Mireille ${ }^{2}$
}

${ }^{1}$ Institut de Recherche pour le Développement (IRD) - UMR 241-EIO, PO Box 529, 98713 Papeete, Tahiti, French Polynesia

2 Institut Louis Malardé (ILM), Laboratory of Toxic Microalgae - UMR 241-EIO, PO Box 30, 98713

Papeete, Tahiti, French Polynesia

${ }^{3}$ Université de la Polynésie Française (UPF) - UMR 241-EIO, PO Box 6570, 98702 Faa'a, Tahiti,

French Polynesia

${ }^{4}$ Institut Français de Recherche pour l'Exploitation de la Mer (IFREMER), Phycotoxins Laboratory, PO Box 21105, 44311 Nantes, France

* Corresponding author: Mélanie Roué, Tel.: +68940474 216 ; fax: +68940429555;

email address : melanie.roue@ird.fr

\begin{abstract}
:
Ciguatera Fish Poisoning (CFP) is a foodborne disease classically related to the consumption of tropical coral reef fishes contaminated with ciguatoxins (CTXs), neurotoxins produced by dinoflagellates of the Gambierdiscus genus. Severe atypical ciguatera-like incidents involving giant clams, a marine resource highly consumed in the South Pacific, are also frequently reported in many Pacific Islands Countries and Territories. The present study was designed to assess the ability of giant clams to accumulate CTXs in their tissues and highlight the potential health risks associated with their consumption. Since giant clams are likely to be exposed to both free-swimming Gambierdiscus cells and dissolved CTXs in natural environment, ex situ contamination experiments were conducted as follows: giant clams were exposed to live or lyzed cells of TB92, a highly toxic strain of $G$. polynesiensis containing $5.83 \pm 0.85 \mathrm{pg}$ P-CTX-3C equiv. cell ${ }^{-1} v s$. HIT0, a weakly toxic strain of $G$. toxicus containing only $(2.05 \pm 1.16) \times 10^{-3} \mathrm{pg} \mathrm{P}$-CTX-3C equiv. cell ${ }^{-1}$, administered over a $48 \mathrm{~h}$ period at a concentration of 150 cells $\mathrm{mL}^{-1}$. The presence of CTXs in giant clams tissues was further assessed using the mouse neuroblastoma cell-based assay (CBA-N2a). Results showed that giant clams exposed to either lyzed or live cells of TB92 were able to bioaccumulate CTXs at concentrations well above the safety limit recommended for human consumption, i.e. $3.28 \pm 1.37$ and $2.92 \pm 1.03 \mathrm{ng}$ P-CTX-3C equiv. $\mathrm{g}^{-1}$ flesh (wet weight), respectively, which represented approximately $3 \%$ of the total toxin load administered to the animals. In contrast, giant clams exposed to live or lyzed cells of HITO were found to be free of toxins, suggesting that in the nature, the risk of contamination of these bivalves is established only in the presence of highly toxic blooms of Gambierdiscus. Liquid chromatography-mass spectrometry (LCMS/MS) analyses confirmed CBA-N2a results and also revealed that P-CTX-3B was the major CTX congener retained in the tissues of giant clams fed with TB92 cells. To the best of our knowledge, this
\end{abstract}


study is the first to provide evidence of the bioaccumulation of Gambierdiscus CTXs in giant clams and confirms that these bivalve molluscs can actually constitute another pathway in ciguatera poisonings. While most monitoring programs currently focus on fish toxicity, these findings stress the importance of a concomitant surveillance of these marine invertebrates in applicable locations for an accurate assessment of ciguatera risk.

\section{Highlights}

- Giant clams were experimentally exposed to highly toxic cells of G. polynesiensis. Activities typical of ciguatoxins were detected in toxic giant clams using CBA-N2a. Chromatographic analyses confirmed the presence of P-CTX-3B in toxic giant clams. These results confirm bioaccumulation of algal CTXs in giant clams. Giant clams could constitute another pathway in the ciguatera food chain.

Keywords: Giant clams, Ex situ contamination, Ciguatoxins, Gambierdiscus polynesiensis, LCMS/MS, Neuroblastoma cell-based assay 


\section{Introduction}

Ciguatera Fish Poisoning (CFP) is the most common non-bacterial seafood intoxication globally and is responsible for more cases of human poisonings than all other marine toxins combined (Fleming et al., 2006; EFSA, 2010a). Although this phenomenon is also endemic in the Caribbean and the Indian Ocean, the most affected regions remain the Pacific Island Countries and Territories (PICTs) (Skinner et al., 2011) where local populations are dependent on seafood for subsistence but also for fishery and tourism industries. Ciguatera is classically related to the consumption of tropical coral reef fish contaminated with ciguatoxins (CTXs), neurotoxins produced by dinoflagellates of the Gambierdiscus genus (Bagnis et al., 1980; Dickey and Plakas, 2010). Reports of atypical ciguatera-like intoxications following the consumption of marine invertebrates highly popular among local populations (giant clams, urchins, trochus) have also been documented in several PICTs (Chinain et al., 2010a; Rongo and van Woesik, 2011; Laurent et al., 2012; Pawlowiez et al., 2013; Gatti et al., 2015). During these intoxications attributed to marine invertebrates, classical symptoms of CFP were observed (gastrointestinal disorders, reversal of hot and cold sensations, itching, paresthesia, asthenia, muscular pain, dizziness), in addition to atypical symptoms (alteration of the taste, burning sensation on the tongue and the throat, paralysis), leading to numerous hospitalizations (Laurent et al., 2012). Based on these complex symptomatology of unusual severity, authors have speculated on the implication of several toxins, including CTX-like toxins, likely from various microbial origins. In French Polynesia, official reports of poisoning incidents following the consumption of marine invertebrates represent less than 10 cases/year whereas an average of 300 fish poisoning cases/year were officially reported in the last five years (www.ciguatera-online.com). Their number may be largely underestimated however, as marine invertebrates meals are often omitted in clinical reports while fish meals are rather incriminated (Pawlowiez et al., 2013).

Giant clams (Tridacna sp., Tridacnidae) are among the most common marine invertebrates involved in these atypical ciguatera-like outbreaks. The first cases were reported in the 1960's, in Bora Bora (Society archipelago, French Polynesia), where 33 people were seriously poisoned after 
the consumption of giant clams, leading to the death of three people (Bagnis, 1967). A triple vasomotor, digestive and nervous syndrome was reported, in agreement with the typical symptoms of CFP. The analysis of some specimens confirmed their toxicity and preliminary chemical analysis suggested the co-occurrence of two toxins, one water-soluble and the second liposoluble, as CTXs (Banner, 1967). Later, in the 1970's, an epidemiological survey of CFP conducted in Gambier archipelago (French Polynesia) established that giant clams were responsible for $4 \%$ of all reported cases (Bagnis, 1974). Since 2005, poisonings after ingestion of giant clams (T. maxima) were recorded in Cook Islands (Rarotonga), French Polynesia (Raivavae, Australes archipelago), New-Caledonia (Lifou) and Republic of Vanuatu (Emao) (Rongo and van Woesik, 2011; Laurent et al., 2012). Although the exact nature of the toxic compounds could not be fully characterized, toxicological analyses using RBA (Radioligand Binding Assay) and CBA-N2a (neuroblastoma cell-based assay) did confirm the presence of liposoluble toxins with an activity on voltage-gated sodium channels (VGSCs) similar to that of CTXs, and whose chemical properties were very closed to those of CTXs (Laurent et al., 2008; Laurent et al., 2012; Pawlowiez et al., 2013). These results have led the authors to speculate on the presence of CTXs (or compounds similar to CTXs) in toxic giant clams.

Giant clams rely greatly on autotrophy (translocation of photosynthates from zooxanthellae symbionts), potentially capable of satisfying all their basal metabolic requirements for metabolism and growth. Heterotrophy (filter-feeding) however may also contribute to the nutrition of giant clams to a lesser extent, especially during the juvenile stage (Heslinga and Fitt, 1987; Klumpp et al. 1992; Fitt, 1993; Klumpp and Griffiths, 1994; Hawkins and Klumpp, 1995). Indeed, giant clams possess the functional feeding and digestive systems that typify heterotrophic filter-feeding bivalves (Yonge, 1980; Reid et al., 1984) and they can filter large quantities of seawater (Pearson and Munro, 1991; Chantrapornsyl et al., 1996). Fitt et al. (1986) demonstrated ingestion and digestion of ${ }^{14} \mathrm{C}$ labeled phytoplancton cells by Tridacna gigas, and Klumpp et al. (1992) showed that $T$. gigas is an efficient filter-feeder, capable of retaining most particles between 2 and $50 \mu \mathrm{m}$. Due to their tychopelagic life style, Gambierdiscus cells can temporarily become free-swimming in the water 
column (Parsons et al., 2011) while senescent cells can also release dissolved CTXs in the surrounding water, especially in high-energy environments. It is thus likely that giant clams living in areas that are contaminated with toxic Gambierdiscus blooms can potentially bioaccumulate CTXs in their tissues.

The present study was performed to test this hypothesis and to assess the ability of giant clams to accumulate CTXs upon an episodic exposure to Gambierdiscus cells, with resulting potential health risks for consumers. To this end, ex situ contamination experiments of giant clams with either live or lyzed cells of TB92, a highly toxic strain of G. polynesiensis were conducted. In addition, preliminary contamination assays with HIT0, a weakly toxic strain of G. toxicus were also performed to assess if contamination is likely to occur in giant clams upon a $48 \mathrm{~h}$ exposure to low toxic Gambierdiscus cells. The potential presence of CTXs congeners in giant clams was further assessed using the mouse neuroblastoma cell-based assay (CBA-N2a) and liquid chromatography - tandem mass spectrometry (LC-MS/MS) analyses.

\section{Material and methods}

\subsection{Biological material}

\subsubsection{Giant clams}

Giant clams (Tridacna maxima) used in this study were purchased from an aquaculture farm in Tahiti (French Polynesia). They had a mean shell length of $14.8 \pm 2.0 \mathrm{~cm}$, a mean shell height of $9.4 \pm$ $1.4 \mathrm{~cm}$ and a mean flesh wet weight of $64.9 \pm 19.9 \mathrm{~g}$.

\subsubsection{Culture of Gambierdiscus strains}

Two reference strains obtained from the algal collection of Louis Malardé Institute were used for the ex situ contamination experiments: Gambierdiscus polynesiensis - TB92 (Tubuai, Australes archipelago, French Polynesia) and G. toxicus - HITO (Tahiti, Society archipelago, French Polynesia) (Chinain et al., 1999, 2010b). Their toxic potencies were quantified using CBA-N2a prior to the contamination experiments (Section 3.1., Fig. 1). 
Cultures of TB92 and HIT0 were established in Fernbach flasks containing 1.25 L of f10k enriched natural seawater medium (Holmes et al., 1991) inoculated at an initial cell density of 250-370 cells $\mathrm{mL}^{-1}$, and were grown at $26 \pm 1{ }^{\circ} \mathrm{C}$ under $100 \mu \mathrm{mol}$ photons $\mathrm{m}^{-2} \mathrm{~s}^{-1}$ of light (daylight fluorescent tubes) in a 12:12 h (light:dark) photoperiod and permanent aeration. Cultures were harvested in their late exponential/early stationary growth phase (i.e. 28 days post-inoculation) when cells exhibit highest CTX levels.

\subsection{Ex situ contamination of giant clams with Gambierdiscus sp. cells}

Contaminations were conducted in closed environment, in tanks containing 20 L of seawater with a salinity value of 37 . The temperature and the percentage of dissolved oxygen were stabilized at around $28{ }^{\circ} \mathrm{C}$ and $8 \mathrm{mg} \mathrm{L}^{-1}$, respectively, and controlled daily. The light regime followed a $12: 12 \mathrm{~h}$ (light:dark) photoperiod with an average irradiance of about $50 \mu \mathrm{mol}$ photons $\mathrm{m}^{-2} \mathrm{~s}^{-1}$ of light (daylight fluorescent tubes). Three giant clams were placed in each experimental tank and acclimated during three days prior to the contamination assays. Two distinct series of ex situ contaminations were conducted, using lyzed and live Gambierdiscus sp. cells, respectively. For each series, the procedure was as follows: 3 tanks and 1 tank in which giant clams were exposed to TB92 and HITO cells, respectively, while a fifth tank containing animals kept in the same environmental conditions as exposed animals served as control.

For experiments using live cells, a cell dose of 150,000 cells was administered 20 times to animals over a contamination period of $48 \mathrm{~h}$, to reach a total cell load of $3 \times 10^{6}$ cells per tank, corresponding to a concentration of 150 cells $\mathrm{mL}^{-1}$. Prior to contamination experiments using lyzed cells, TB92 and HITO cell lysates were prepared using an ultrasonic probe $(3 \times 10 \mathrm{~min}$ in ice, pulse mode, 30\% amplitude). The resulting samples, containing both dissolved CTXs and cellular debris, were then administered in a single dose of $3 \times 10^{6}$ cells per tank. Each tank was equipped with a pump set at a flow rate of $200 \mathrm{~L} \mathrm{~h}^{-1}$, in order to favor the suspension and/or dissemination of Gambierdiscus cells/dissolved toxins in the surround environment of giant clams. 
All giant clams were sacrificed $48 \mathrm{~h}$ after the beginning of the contamination experiments. For each animal, the whole meat was extracted from the shell and thoroughly rinsed twice in $0.5 \mathrm{~L}$ seawater in order to remove all trace of incubation water potentially contaminated with either dissolved CTXs or Gambierdiscus cells. Each sample was then ground separately and stored at $-20^{\circ} \mathrm{C}$. Prior to the extraction step, a subsample of $4 \mathrm{~g}$ was taken from each animal. The subsamples corresponding to the three giant clams from the same experimental tank were then pooled to give a total sample of $12 \mathrm{~g}$ (wet weight) per tank.

\subsection{Toxin extraction}

The extraction protocol used in this study was adapted from Laurent et al. (2012) and Pawlowiez et al. (2013). Giant clams samples (12 g) were extracted twice in $20 \mathrm{~mL}$ of methanol $(\mathrm{MeOH})$ and twice in $20 \mathrm{~mL}$ of $50 \%$ aqueous $\mathrm{MeOH}$, under sonication for $4 \mathrm{~h}$. After incubation at $-20^{\circ} \mathrm{C}$ overnight, followed by a centrifugation step, the resulting supernatants were pooled $(80 \mathrm{~mL})$ and dried under vacuum. The resulting dried extracts were further partitioned between $50 \mathrm{~mL}$ of dichloromethane $\left(\mathrm{CH}_{2} \mathrm{Cl}_{2}\right)$ and $2 \times 25 \mathrm{~mL}$ of $60 \%$ aqueous $\mathrm{MeOH}$. The dichloromethane phases, likely to contain $\mathrm{CTXs}$, were dried under vacuum and defatted by a second solvent partition using $2 \times 40 \mathrm{~mL}$ of cyclohexane and $20 \mathrm{~mL}$ of $80 \%$ aqueous $\mathrm{MeOH}$. The methanolic fractions were retrieved and dried under vacuum in view of their purification by SPE techniques. To this end, the resulting dried extracts were resuspended in $4 \mathrm{~mL}$ of $70 \%$ aqueous $\mathrm{MeOH}$ and then loaded on $\mathrm{C}_{18}$ Sep-Pak cartridges (Waters ${ }^{\circledR}$ ) which were pre-conditioned with $7 \mathrm{~mL}$ of $70 \%$ aqueous $\mathrm{MeOH}$. After an initial washing step with 7 $\mathrm{mL}$ of $70 \%$ aqueous methanol, each column was eluted with $7 \mathrm{~mL}$ of $90 \%$ aqueous methanol. The resulting fractions, likely to contain CTXs, were further dried in a SpeedVac concentrator and stored at $+4{ }^{\circ} \mathrm{C}$ until tested for their toxicity.

The toxic status of strains TB92 and HITO were also verified prior to contamination experiments: cell pellets containing $1 \times 10^{6}$ cells were extracted 3 times in $30 \mathrm{~mL}$ of $\mathrm{MeOH}$ under sonication, using an ultrasonic probe (10 min in ice, pulse mode, 30\% amplitude). After centrifugation, supernatants 
were pooled and dried under vacuum. The resulting crude extracts were subjected to further purification steps following the protocol described for giant clams, excluding the delipidation step.

All fractions were weighed and re-suspended in methanol to reach a final concentration of $1 \mathrm{mg}$ of dry extract/100 $\mu \mathrm{L}$ prior to CBA-N2a toxicological analyses.

\subsection{Neuroblastoma cell-based assays (CBA-N2a)}

The neuroblastoma cell-based assay (CBA-N2a) is widely used for the detection of a wide range of marine neurotoxins active on the VGSCs (Caillaud et al., 2010; Nicolas et al., 2014; Reverté et al., 2014). This toxicological assay classically uses a combination of ouabain (blocker of the $\mathrm{Na}^{+} / \mathrm{K}^{+}$ ATPase pump) and veratridine (inductor of permanent activation of VGSCs), at selected concentrations, for the specific detection of CTXs (Manger et al., 1993; Cañete and Diogène, 2008; Caillaud et al., 2009). The procedure used in this work was adapted from the method proposed by Pawlowiez et al. (2013), and modified as follows to reach optimum repeatability and reproducibility of the assays.

A density of 45,000 neuroblastoma cells $/ 200 \mu \mathrm{L} /$ well in $5 \%$ fetal bovine serum RPMI-1640 supplemented medium was seeded in a 96-well microtiter plate in order to reach around $100 \%$ confluence after $20-24 \mathrm{~h}$ of incubation at $37{ }^{\circ} \mathrm{C}$ in a humidified $5 \% \mathrm{CO}_{2}$ atmosphere. After $20-24 \mathrm{~h}$, the culture medium was replaced by $200 \mu \mathrm{L}$ of $2 \%$ FBS RPMI-1640 for half of the wells and by $200 \mu \mathrm{L}$ of the same medium containing an ouabain-veratridine solution (OV) for the other half of the wells. The working concentration for OV solution was $80 / 8 \mu \mathrm{M}$ in order to obtain $90-100 \%$ of cell viability against control cells in $\mathrm{OV}^{-}$conditions. Untreated cells and treated cells $\left(\mathrm{OV}^{+}\right.$conditions) were then exposed to increasing concentrations of either CTX standards or samples extracts, in triplicate per plate. After a $20-22 \mathrm{~h}$ incubation time, cell viability was assessed by removing the incubation medium, and $60 \mu \mathrm{L}$ of RPMI-1640 medium containing $0.8 \mathrm{mg} \mathrm{mL}^{-1}$ of 3-(4,5-dimethylthiazol-2-yl)-2,5diphenyl tetrazolium bromide (MTT) was added to each well. The plates were incubated for $37 \mathrm{~min}$ at $37^{\circ} \mathrm{C}$. Finally, the MTT was discarded and $100 \mu \mathrm{L}$ of dimethyl sulphoxide (DMSO) was added to each 
well to dissolve the formazan. The absorbance was read at $570 \mathrm{~nm}$ on a plate reader (iMark Microplate Absorbance Reader, BioRad, Marnes la Coquette, France). For all experiments, the absorbance values obtained for $\mathrm{OV}^{-}$and $\mathrm{OV}^{+}$control wells were around $0.9-1$, corresponding to $100 \%$ viability.

The calibration of CBA-N2a was achieved using three P-CTX standards: P-CTX-3C, P-CTX-3B and PCTX-1B obtained from the Louis Malardé Institute's bank of standards. Untreated cells and treated cells were exposed to eight distinct concentrations (prepared from a 1:2 serial dilution) of each CTX standard, ranging from [0.37 to 47.62], [0.07 to 9.52], [0.7 to 95.2] fg $\mu \mathrm{L}^{-1}$ for $\mathrm{P}-\mathrm{CTX}-3 \mathrm{C}, \mathrm{P}-\mathrm{CTX}-3 \mathrm{~B}$ and $\mathrm{P}-\mathrm{CTX}-1 \mathrm{~B}$, respectively. Each concentration was tested in $\mathrm{OV}^{-}$and $\mathrm{OV}^{+}$conditions, in triplicate per plate, in at least three independent experiments. Under $\mathrm{OV}^{+}$conditions, Neuro-2a cells typically display a sigmoidal dose-response curve in the presence of CTXs, whereas no cytotoxicity is observed under $\mathrm{OV}^{-}$conditions. The half maximal effective concentration $\left(\mathrm{EC}_{50}\right)$ values \pm standard deviations (SD) obtained for P-CTX-1B, P-CTX-3C and P-CTX-3B were $1.63 \pm 0.22$ ( $n=5$ experiments), $3.10 \pm 0.76$ $(n=11)$ and $17.69 \pm 1.36(n=3) \mathrm{fg} \mu \mathrm{L}^{-1}$, respectively.

To address the issue of potential matrix interferences likely to cause non-specific cytotoxicity in Neuro-2a cells, the maximum concentration of dry extracts (MCE) to be tested in CBA-N2a (Caillaud et al., 2012; Pawlowiez et al., 2013) was also determined. Then, cytotoxic effects observed on Neuro-

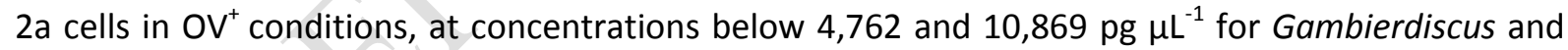
giant clam dry extracts, respectively, could be regarded as indicative of the presence of CTXs in these extracts. Practically, these MCE correspond to 5.29 cell equiv. $\mu \mathrm{L}^{-1}$ and $63.4 \mu \mathrm{g}$ wet weight of flesh equiv. $\mu \mathrm{L}^{-1}$ for Gambierdiscus and giant clam dry extracts, respectively. In order to get a full CBA-N2a curve, TB92 and HITO dry extracts were tested at a concentration range of [0.11 - 14.29] and [37 4,762] $\mathrm{pg} \mathrm{mL} \mathrm{m}^{-1}$, respectively, whereas toxic and non-toxic giant clam dry extracts were tested at a concentration range of $[15-1,905]$ and $[84.9-10,869] \mathrm{pg} \mu \mathrm{L}^{-1}$, respectively. Each concentration was tested in $\mathrm{OV}^{-}$and $\mathrm{OV}^{+}$conditions, in triplicate per plate, in at least three independent experiments. 


\subsection{Data analysis}

The percentage of viability ( $\mathrm{V}_{\mathrm{CBA}-\mathrm{N2} 2}$ ) obtained in CBA-N2a assays was calculated as follows:

$\mathrm{V}_{\mathrm{CBA}-\mathrm{N2a}}=\left(\right.$ Mean absorbance of control wells $\mathrm{OV}^{+} /$Mean absorbance of control wells $\left.\mathrm{OV}^{-}\right) \times 100$

This value should be around $90 \pm 10 \%$.

For ciguatoxin standards and samples, cell viability for each concentration tested $\left(C_{x}\right)$ in OV $^{-}$ $\left(\mathrm{VS}_{\mathrm{CXOV}_{-}}\right)$and $\mathrm{OV}^{+}\left(\mathrm{VS}_{\mathrm{CXOV}_{+}}\right)$conditions were obtained as follows:

$\mathrm{VS}_{\mathrm{CxOV}-}=\left(\right.$ Mean absorbance of $\mathrm{Cx}$ wells $\mathrm{OV}^{-} /$Mean absorbance of control wells OV $) \times 100$

$\mathrm{VS}_{\mathrm{CxOV}_{+}}=\left(\right.$Mean absorbance of $\mathrm{Cx}$ wells $\mathrm{OV}^{+} /$Mean absorbance of control wells $\left.\mathrm{OV}^{+}\right) \times 100$

Viability data were fitted to a sigmoidal dose-response curve (variable slope) allowing the calculation of $\mathrm{EC}_{50}$ values using Prism v6.0.7 software (GraphPad, San Diego, CA, USA). Since raw results for all extracts were obtained in $\mathrm{pg} \mu \mathrm{L}^{-1}$, the $\mathrm{EC}_{50}$ values for Gambierdiscus and giant clam samples were further expressed in cell equiv. $\mu \mathrm{L}^{-1}$ and g wet weight of flesh equiv. $\mu \mathrm{L}^{-1}$, respectively.

Finally, the toxin content $(T)$ in these two types of biological matrices was estimated using the following formula $T=\left(\mathrm{P}-\mathrm{CTX}-3 \mathrm{C} \mathrm{EC}_{50} /\right.$ sample $\left.\mathrm{EC}_{50}\right)$, expressed in $\mathrm{pg} \mathrm{P}-\mathrm{CTX}-3 \mathrm{C}$ equiv. cell $^{-1}$ for Gambierdiscus, or in ng P-CTX-3C equiv. $\mathrm{g}^{-1}$ wet weight of flesh for giant clams. To make comparisons with former studies easier, $(T)$ values can be converted into P-CTX-1B equiv. using the following formula: $\mathrm{T}=$ (toxin content values in P-CTX-3C equiv. / 1.9). In the conditions of this study, the limit of quantification (LOQ) for CBA-N2a estimated according to the method of Caillaud et al. (2012) was 168 pg P-CTX-3C equiv. cell ${ }^{-1}$ and 14 ng P-CTX-3C equiv. $\mathrm{mg}^{-1}$ wet weight of flesh for Gambierdiscus and giant clam extracts, respectively.

\subsection{Liquid chromatography - tandem mass spectrometry analyses (LC-MS/MS)}

The procedure for liquid chromatography coupled with tandem mass spectrometry (LC-MS/MS) analyses was adapted from the method described by Lewis et al. (2009) and Stewart et al. (2010). Analyses were carried out on Gambierdiscus and giant clams dry extracts using a LC system (UFLC Nexera, SHIMADZU) coupled to a hybrid triple quadrupole/ion-trap mass spectrometer 
(API4000Qtrap, ABSCIEX) equipped with a turbo spray ${ }^{\circledR}$ interface. A Kinetex column $\left(\mathrm{C}_{18}, 2.6 \mu \mathrm{m}, 50\right.$ $\mathrm{mm} \times 2.1 \mathrm{~mm}$, Phenomenex) was employed at $40{ }^{\circ} \mathrm{C}$ and P-CTXs were eluted at $400 \mu \mathrm{L} \mathrm{min}{ }^{-1}$ with a linear gradient using water as eluent A and $95 \%$ acetonitrile/water as eluent B, both eluents containing $2 \mathrm{mM}$ ammonium formate and $50 \mathrm{mM}$ formic acid. Five microliters of sample was injected onto the column. The instrument control, data processing and analysis were conducted using Analyst software. Mass spectrometry detection was performed in positive mode using Multi Reaction Monitoring (MRM). The pseudomolecular ions $\left[\mathrm{M}+\mathrm{NH}_{4}\right]^{+}$and $[\mathrm{M}+\mathrm{H}]^{+}$were selected as precursor ions. The ions resulting in the successive losses of water molecules were selected as product ions (Table 1). The MRM experiments were established by using the following source settings: curtain gas set at 25 , ion spray at $5500 \mathrm{~V}$, a turbogas temperature of $300{ }^{\circ} \mathrm{C}$, gas 1 set at 40 and gas 2 set at 60 psi with an entrance potential of $10 \mathrm{~V}$. The calibration of LC-MS/MS method was achieved using three P-CTX standards: P-CTX-1B, P-CTX-3B and P-CTX-3C, obtained from the Louis Malardé Institute's bank of standards. The limit of detection (LOD) was estimated to $0.06 \mu \mathrm{g}$ P-CTX-3C $\mathrm{mL}^{-1}$.

\section{Results}

\subsection{Toxicity of strains TB92 and HITO}

Strain TB92 displayed a high toxic potency in $\mathrm{OV}^{+}$conditions with a sigmoidal dose-response curve whereas no cytotoxic effects were observed on Neuro-2a cells in $\mathrm{OV}^{-}$conditions, a response typical of CTX bioactivity (Fig. 1). The $\mathrm{EC}_{50}$ value for TB92 was $(5.39 \pm 0.83) \times 10^{-4}$ cell equiv. $\mathrm{LL}^{-1}$, corresponding to a toxin content of $5.83 \pm 0.85 \mathrm{pg}$ P-CTX-3C equiv. cell ${ }^{-1}$. In contrast, strain HITO was found to be weakly toxic in CBA-N2a, showing an $\mathrm{EC}_{50}$ of $1.82 \pm 0.81$ cell equiv. $\mu \mathrm{L}^{-1}$, corresponding to a toxin content of $(2.05 \pm 1.16) \times 10^{-3} \mathrm{pg} \mathrm{P-CTX-3C} \mathrm{equiv.} \mathrm{cell}{ }^{-1}$ (Fig. 1$)$.

Chemical analyses (LC-MS/MS) of strain TB92 revealed seven CTXs peaks (Fig. 2) corresponding to $\mathrm{P}-\mathrm{CTX}-3 \mathrm{~B}$ (retention time RT $=5.65 \mathrm{~min}), \mathrm{P}-\mathrm{CTX}-3 \mathrm{C}(\mathrm{RT}=5.80 \mathrm{~min}), \mathrm{P}-\mathrm{CTX}-3 \mathrm{C} / 3 \mathrm{~B}$ analogs $(\mathrm{RT}=4.11$ and $4.48 \mathrm{~min}), \mathrm{P}-\mathrm{CTX}-4 \mathrm{~A}(\mathrm{RT}=5.87 \mathrm{~min}), \mathrm{P}-\mathrm{CTX}-4 \mathrm{~B}(\mathrm{RT}=6.21 \mathrm{~min})$ and $\mathrm{M}-\mathrm{seco}-\mathrm{P}-\mathrm{CTX}-4 \mathrm{~A}(\mathrm{RT}=4.94$ 
min) (tentative identifications based on MRM transitions, except for P-CTX-3C and P-CTX-3B for which standards were available, see Table 1). No CTXs were detected in strain HITO (data not shown).

\subsection{Toxicity of giant clam samples}

No mortality incident was observed among the tested animals during the acclimation step, nor in the course of the contamination experiments.

Extracts obtained from control animals and giant clams exposed to either lyzed or live cells of HITO showed no toxicity in CBA-N2a (data not shown). Likewise, LC-MS/MS analyses confirmed the absence of CTXs in these fractions (Fig. 3B).

Conversely, all six extracts obtained from giant clams exposed to either lyzed $(n=3)$ or live cells ( $n$ = 3) of TB92 were found toxic in CBA-N2a assays, with a sigmoidal dose-response curve typical of the presence of CTXs (Fig. 4). Mean $\mathrm{EC}_{50}$ values of $1.00 \pm 0.42$ and $1.17 \pm 0.13 \mu \mathrm{g}$ wet weight of flesh equiv. $\mu \mathrm{L}^{-1}$, corresponding to mean toxin contents of $3.28 \pm 1.37$ and $2.92 \pm 1.03 \mathrm{ng} \mathrm{P}-\mathrm{CTX}-3 \mathrm{C}$ equiv. $\mathrm{g}^{-}$

${ }^{1}$ flesh (wet weight) for giant clams exposed to lyzed and live cells, respectively, were obtained (Table 2 ), with no significant difference observed between these values (Student's $t$ test, $p>0.05$ ). These findings were confirmed by LC-MS/MS analysis which showed the presence of a single peak corresponding to P-CTX-3B (RT = $5.65 \mathrm{~min}$ ) in the flesh of toxic animals (Fig. 3C, Table 1).

Based on the contamination protocol, each pool of three giant clams placed in $20 \mathrm{~L}$ tank and exposed to TB92 cells received a total toxin load of $17.25 \mu \mathrm{g}$ P-CTX-3C equiv., or $0.86 \mu \mathrm{g}$ P-CTX-3C equiv. $\mathrm{L}^{-1}$ (contamination with $3 \times 10^{6}$ TB92 cells with an average toxic potency of $5.83 \pm 0.85 \mathrm{pg} \mathrm{P}$ CTX-3C equiv. cell $\left.{ }^{-1}\right)$. Consequently, it was estimated that each pool of exposed animals was actually able to retain approximately $3.65 \pm 1.34$ and $3.06 \pm 0.96 \%$ of the toxins administered in each tank for lyzed and live TB92 cells conditions, respectively (Table 2). In contrast, each pool of three giant clams exposed to HITO cells received a total toxin load of $6.15 \times 10^{-3} \mu \mathrm{g}$ P-CTX-3C equiv. or $0.31 \times 10^{-3} \mu \mathrm{g} \mathrm{P-}$ CTX-3C equiv. $\mathrm{L}^{-1}$ (i.e. contamination with $3 \times 10^{6}$ HITO cells with an average toxic potency of $(2.05 \pm$ 
1.16) $\times 10^{-3} \mathrm{pg} \mathrm{P-CTX-3C}$ equiv. cell $\left.{ }^{-1}\right)$, which appeared insufficient to induce toxin accumulation in these giant clams.

\section{Discussion}

Coral reef fish are widely regarded as the main vectors of ciguatera. Based on previous reports of severe atypical ciguatera-like intoxications involving giant clams (Tridacna maxima) in several island communities of the South Pacific (Rongo and van Woesik, 2011; Laurent et al., 2012; Pawlowiez et al., 2013), the possibility that this bivalve mollusc could also represent another potential vector of CTXs was suggested. To this end, two series of experimental contaminations using either live or lyzed cells of Gambierdiscus were performed, followed by CBA-N2a and LC-MS/MS analyses to determine whether giant clams were able to bioaccumulate algal CTXs in their tissues.

Results of CBA-N2a analysis indicated that giant clams exposed to either live or lyzed cells of TB92, a highly toxic strain of Gambierdiscus polynesiensis, were able to retain CTXs in their tissues, suggesting the existence of two uptake routes in this bivalve: either by direct ingestion of toxic Gambierdiscus cells dispersed in the water column, or by filtration of seawater containing dissolved CTXs. Interestingly, previous contamination studies of Mytilus edulis with Azadinium spinosum, a known producer of azaspiracids (AZAs), have led to similar findings with the accumulation of AZAs in blue mussels both from lyzed and live Azadinium cells, but also from toxins dissolved directly in the seawater (Jauffrais et al., 2012, 2013). These authors speculated that partial adsorption of dissolved AZAs onto cellular debris (lyzed cells) or non-toxic cells, followed by their ingestion by the mussels, may favor toxin accumulation in $M$. edulis digestive gland, whereas dissolved AZAs alone were preferentially found in gills. In the present study, CTXs were not dissolved directly in the seawater but administered in the form of a cell lysate containing cellular debris. The fact that similar toxin levels were observed in giant clams exposed to either intact or lyzed cells is consistent with the hypothesis of Jauffrais et al. (2013) and suggests a digestive uptake route. Since the CBA-N2a analyses were not performed on separate tissues but on the whole animal body, a concomitant 
uptake of dissolved CTXs through the ctenidia of giant clams cannot, however, be ruled out. Likewise, even though the exposed animals were subjected to a thorough rinse prior to their extraction, a possible sticking of benthic Gambierdiscus cells or incidental adsorption of dissolved CTXs onto tissue surface of giant clams are also likely. In any case, unlike control animals, giant clams experimentally exposed to TB92 eventually became toxic, suggesting that a similar event is likely to occur in the natural environment.

Numerous contamination studies using various toxic dinoflagellates (Alexandrium, Ostreopsis, Azadinium) have been previously conducted on a variety of bivalve molluscs such as mussels, scallops, oysters, and clams (Rhodes et al., 2002; Rolland et al., 2012; Jauffrais et al., 2012, 2013; Haberkorn et al., 2014). Although animals were consistently exposed to higher concentrations of toxic cells in these experiments, ranging from $1 \times 10^{3}$ to $1 \times 10^{5}$ cells $\mathrm{mL}^{-1}$, the total toxin loads supplied to target animals were estimated to be of the same order of magnitude as in the present study : i.e. 1 to $6.5 \mu \mathrm{g} \mathrm{STX} \mathrm{equiv.} \mathrm{L}^{-1}$ for Alexandrium (Rolland et al., 2012; Haberkorn et al., 2014), $0.45 \mu \mathrm{g}$ PLTX equiv. $\mathrm{L}^{-1}$ for Ostreopsis (Rhodes et al., 2002), and 0.75-7.5 $\mu \mathrm{g}$ AZAs L $^{-1}$ for Azadinium (Jauffrais et al., 2012, 2013). The only difference lies in the fact that giant clams are organisms much bigger in size than the species tested in these previous studies. In any case, the cell concentrations that were used in the present work, e.g. $3 \times 10^{6}$ cells (or 150 cells $\mathrm{mL}^{-1}$ ) corresponding to a total toxin load of $17.25 \mu$ P P-CTX-3C equiv. per experimental tank, are representative of what can be found in natural blooms. Indeed, previous studies conducted in various ciguateric sites of French Polynesia by Yasumoto et al. (1980) and Chinain et al. (1999) showed that cell abundance up to 318,000 and 11,000 cells $\mathrm{g}^{-1}$ of algae, respectively, can occur in natural environment, which represented an overall toxicity that may reach $48 \mu \mathrm{g}$ P-CTX-3C equiv. in some of these natural blooms (Chinain et al, 1999).

When exposed to TB92 toxic cells for $48 \mathrm{~h}$, giant clams were able to retain an average of $3 \mathrm{ng}$ PCTX-3C equiv. $\mathrm{g}^{-1}$ in their tissues, which represented only $~ 3 \%$ of the total toxin load supplied. There are several possible explanations to this low toxin uptake rate. Firstly, although a pump was used in order to favor the permanent resuspension of cells in the water column, part of the Gambierdiscus 
cells or dissolved CTXs adsorbed onto cellular debris may have decanted and were thus no longer bioavailable for ingestion by giant clams, leading to a low accumulation of CTXs in their tissues. Secondly, giant clams may have poor retention potential for CTXs, leading to the rapid elimination of toxins within a few hours. Indeed, previous studies by Tosteson et al. (1988), Lewis et al. (1992) and Ledreux et al. (2014) have shown that in fish, CTX concentrations depend on species-specific rates of toxin assimilation and excretion. For example, in the mullet fish Mugil cephalus experimentally fed with freeze-dried cells of TB92, CTXs are rapidly absorbed from the intestinal tract into the systemic circulation of fish, leading to the rapid elimination (within $24 \mathrm{~h}$ ) of $95 \%$ of the ingested toxic dose (Ledreux et al., 2014). Finally, one last explanation for this low toxin uptake by giant clams directly relates to the duration of the experimental contaminations conducted in the present study. Indeed, natural blooms involving benthic microalgal species (e.g. Gambierdiscus) can often persist for several days, especially in low-energy environments of enclosed bays or lagoons. Additionally, in ciguateric areas where successive toxic blooms of Gambierdiscus are sometimes observed over several months or even years (Chinain et al., 1999), sessile molluscs such as giant clams may be subject to "chronic" accumulation of ciguatera toxins. This process may explain why the level of toxicity found in some field specimens collected in areas reputed for their toxicity could reach $60 \mathrm{ng}$ P-CTX-3C equiv. $\mathrm{g}^{-1}$ of flesh (Laurent et al., 2012), a concentration 20-fold higher than the one attained in the present study.

Despite this low toxin uptake rate, the toxin concentrations detected by CBA-N2a in giant clams tissues following their exposure to TB92 toxic cells were found well above the safety limit commonly recommended for human consumption, i.e. $0.01 \mathrm{ppb}$ P-CTX-1B (or $0.02 \mathrm{ppb}$ P-CTX-3C) for Pacific region (EFSA, 2010b; Hossen et al., 2015). Indeed, CTXs are very potent neurotoxins, with a per os $\mathrm{LD}_{50}$ estimated at $20 \mathrm{ng} \mathrm{kg}^{-1}$ human body weight (Pauillac et al., 2003) such that the bioconcentration of less than $2 \mu \mathrm{g}$ of toxins in giant clams tissues is generally considered sufficient to induce intoxications in humans. These findings clearly emphasize the existence of potential health risks associated with the consumption of giant clams in areas where these sessile molluscs are episodically/continuously exposed to toxic Gambierdiscus blooms. 

with a toxicity 2,850-fold lower than in TB92 as evidenced by CBA-N2a toxicity data, did not result in the acute contamination of giant clams. Although preliminary, these findings suggest that, in the natural environment, the risk of contamination of these bivalves is established only in the presence of highly toxic blooms. This hypothesis is coherent with previous observations by Litaker et al. (2010) who highlighted the necessity of developing a hybrid approach in current ciguatera monitoring systems based on both cell densities and direct toxin detection methods, to avoid false alarms about potential CFP risks due to the detection of non-toxic Gambierdiscus cells in the environment. Such

results need however to be confirmed through additional contamination experiments conducted over extended contamination periods and on more replicates.

Chemical analyses (LC-MS/MS) of TB92 cell extracts revealed the presence of multiple P-CTX congeners in this strain: P-CTX-3B, P-CTX-3C, P-CTX-3C/3B analogs, P-CTX-4A, P-CTX-4B and M-secoP-CTX-4A. These findings are consistent with the toxin profile previously characterized for TB92 strain by Chinain et al. (2010b), except that although the same P-CTXs congeners were observed, their distribution differed significantly in the present study, especially regarding P-CTX-3C which was among the minor P-CTX congeners found in TB92 cells used to contaminate giant clams. Such a discrepancy can be easily explained by the fact that, in in vitro conditions, Gambierdiscus strains are known to exhibit substantial variations in CTXs production according to growth stages (Chinain et al., 2010b) but also culture conditions (medium composition, temperature, salinity, irradiance) (Morton et al., 1992; Sperr and Doucette, 1996). Furthermore, LC-MS/MS data also indicated that P-CTX-3B was the only CTX congener retained in the flesh of giant clams following their exposure to TB92 toxic cells. There are many possible explanations to this apparent absence of other algal congeners in contaminated giant clams. Other congeners could have been accumulated in lower concentrations that are under the limit of detection of the LC-MS/MS method used. Or they may have been subjected to further biotransformation process or to faster excretion rate in their host. In any case, all the processes that govern the toxicokinetics of CTXs in giant clams are out of the scope of this 
paper and will be addressed in another study with appropriate experiments. Additional issues such as the distribution patterns of CTXs in the different organs of the mollusc, and the resulting biotransformation processes undergone by Gambierdiscus toxins leading to the formation of new CTXs analogs also need to be addressed.

The present study provides evidence of the ability of giant clams to accumulate CTXs in their tissues and confirms that these molluscs, which are part of the diet of many populations in PICTs, could represent another vector of ciguatera in areas where Gambierdiscus populations are endemic. Besides the potential health risks for consumers, this issue also represents a serious impediment to the development of lagoon fishing in these local communities. For example, in French Polynesia, the local market for consumption of giant clams meat from East Tuamotu and Australes archipelagos is estimated to represent around 70 tons per year (www.peche.pf/spip.php?rubrique213). Furthermore, others marine invertebrates such as bivalves (Atactodea sp.) and gastropods (Tectus niloticus, Nerita sp.) molluscs, or sea urchins (Tripneustes gratilla), were also implicated in atypical ciguatera-like intoxications in French Polynesia, New Caledonia and Republic of Vanuatu (Angibaud et al., 2000; Laurent et al., 2012; Gatti et al., 2015) and are thus also believe to be natural concentrators of CTXs. Hence, the finding that these popular marine invertebrates not usually associated with CFP could potentially be toxic, stresses out the importance of maintaining on-going educational programs to increase awareness in South Pacific local communities, in order to minimize the risk of seafood intoxication not only to local populations but also to tourists, which are also fond of such food.

In conclusion, the mechanisms that govern toxins transfer through lagoon food webs in many locations in the South Pacific appear to be much more complex than initially thought. The present study should contribute in setting up the basis of an improved global strategy in seafood intoxication risk assessment and management programs currently on-going in PICTs, which are so far limited to the survey of lagoon fish. Such monitoring programs should now take into account all major seafood resources mainly consumed within island communities, including those commonly regarded as being at low risk of ciguatera. 


\section{Acknowledgements}

The work described in this paper was supported by funds from the countries of France and French Polynesia (Contrat de Projet "Caractérisation écotoxicologique des lagons exploités" CELEX - n¹922012/VP/DBP). The authors greatly acknowledge Nicolas Maihota and Philippe Cruchet for their technical assistance.

\section{References}

Angibaud, G., Leveque, J.M., Laurent, D., Gaultier, C., 2000. Manifestations neurologiques consécutives à la consommation d’un coquillage du lagon calédonien. Rev. Neurol. (Paris) 156, 6566.

Bagnis, R., 1967. A propos de quelques cas d'intoxications par des mollusques du genre «bénitier» dans une île de la Société. Bull. Soc. Pathol. Exot. 60(6), 580-592.

Bagnis, R., 1974. Situation de l'endémicité ciguatérique aux îles Gambier. Cahiers du Pacifique 18, 585-600.

Bagnis, R., Chanteau, S., Chungue, E., Hurtel, J.M., Yasumoto, T., Inoue, A., 1980. Origins of ciguatera fish poisoning: a new dinoflagellate, Gambierdiscus toxicus Adachi and Fukuyo, definitively involved as a causal agent. Toxicon 18(2), 199-208.

Banner, A.H., 1967. Marine toxins from the Pacific. I. Advances in the investigation of fish toxins. In: Russel, F.E., Saunders, P.R. (Eds.), Animal Toxins. Pergammon Press, Oxford, pp. 157-165.

Caillaud, A., Cañete, E., de la Iglesia, P., Giménez, G., Diogène, J., 2009. Cell-based assay coupled with chromatographic fractioning: a strategy for marine toxins detection in natural samples. Toxicon 23, 1591-1596.

Caillaud, A., de la Iglesia, P., Darius, H.T., Pauillac, S., Aligizaki, K., Fraga, S., Chinain, M., Diogène, J., 2010. Update on methodologies available for ciguatoxin determination: perspectives to confront the onset of ciguatera fish poisoning in Europe. Mar. Drugs 8, 1838-1907. 
Caillaud, A., Eixarch, H., de la Iglesia, P., Rodriguez, M., Dominiquez, L., Andree, K.B., Diogène, J., 2012. Towards the standardisation of the neuroblastoma (neuro-2a) cell-based assay for ciguatoxin-like toxicity detection in fish: application to fish caught in the Canary Islands. Food Addit. Contam. Part A 29, 1000-1010.

Cañete, E., Diogène, J., 2008. Comparative study of the use of neuroblastoma cells (Neuro-2a) and neuroblastoma-xglioma hybrid cells (NG108-15) for the toxic effect quantification of marine toxins. Toxicon 52, 541-550.

Chantrapornsyl, S., Kittiwattanawong, K., Adulyanukosol, K., 1996. Distribution and abundance of giant clam around Lee-Pae Island, the Andaman Sea, Thailand. Phuket Mar. Biol. Center Spec. Publ. 16, 195-200.

Chinain, M., Germain, M., Deparis, X., Pauillac, S., Legrand, A.M., 1999. Seasonal abundance and toxicity of the dinoflagellate Gambierdiscus spp. (Dinophyceae), the causative agent of ciguatera in Tahiti, French Polynesia. Mar. Biol. 135, 259-267.

Chinain, M., Darius, H.T., Ung, A., Tchou Fouc, M., Revel, T., Cruchet, P., Pauillac, S., Laurent, D., 2010a. Ciguatera risk management in French Polynesia: the case study of Raivavae Island (Australes Archipelago). Toxicon 56, 674-690.

Chinain, M., Darius, H.T., Ung, A., Cruchet, P., Wang, Z., Ponton, D., Laurent, D., Pauillac, S., 2010b. Growth and toxin production in the ciguatera-causing dinoflagellate Gambierdiscus polynesiensis (Dinophyceae) in culture. Toxicon 56, 739-750.

Dickey, R.W., Plakas, S.M., 2010. Ciguatera: a public health perspective. Toxicon 56(2), 123-136.

European Food Safety Agency (EFSA), 2010a. EFSA report on data collection: future directions. EFSA J. 8(5), 1533.

European Food Safety Agency (EFSA), 2010b. Scientific opinion on marine biotoxins in shellfish emerging toxins: ciguatoxin group. EFSA J. 8(6), 1627. 
Fitt, W.K., Fisher, C.R., Trench, R.K., 1986. Contribution of the symbiotic dinoflagellate Symbiodinium microadriaticum to the nutrition, growth and survival of larval and juvenile tridacnid clams. Aquaculture 55, 5-22.

Fitt, W.K., 1993. Nutrition of giant clams. In: Fitt, W.K. (ed) Biology Mariculture of Giant Clams. ACIAR Proceedings no. 47, Australian Centre for International Agricultural Research, Canberra, pp 31-40.

Fleming, L.E., Broad, K., Clement, A., Dewailly, E., Elmir, S., Knap, A., Pomponi, S.A., Smith, S., Solo Gabriele, H., Walsh, P., 2006. Oceans and human health: emerging public health risks in the marine environment. Mar. Pollut. Bull. 53(10-12), 545-560.

Gatti, C., Lonatti, D., Darius, H.T., Chinain, M. 2015. First report of a mass-poisoning outbreak following the consumption of Tectus niloticus (Gastropod) in French Polynesia: a novel pathway of Ciguatera Shellfish Poisoning? Harmful Algae News 50, 19-20.

Haberkorn, H., Lambert, C., Le Goïc, N., Quéré, C., Bruneau, A., Riso, R., Auffret, M., Soudant, P., 2014. Cellular and biochemical responses of the oyster Crassostrea gigas to controlled exposures to metals and Alexandrium minutum. Aquat. Toxicol. 147, 158-67.

Hawkins, A.J.S., Klumpp, D.W., 1995. Nutrition of the giant clam Tridacna gigas (L.) II. Relative contributions of filter-feeding and the ammonium-nitrogen acquired and recycled by symbiotic alga towards total nitrogen requirements for tissue-growth and metabolism. J. Exp. Mar. Biol. Ecol. 190, 263-290.

Heslinga, G.A., Fitt, W.K., 1987. The domestication of reef-dwelling clams. Bioscience 37, 332-339.

Holmes, M.J., Lewis, R.J., Poli, M.A., Gillepsie, N.C., 1991. Strain dependent production of ciguatoxin precursors (gambiertoxins) by Gambierdiscus toxicus (Dinophyceae) in culture. Toxicon 29, 761775.

Hossen, V., Soliño, L., Leroy, P., David, E., Velge, P., Dragacci, S., Krys, S., Flores Quintana, H., Diogène, J., 2015. Contribution to the risk characterization of ciguatoxins: LOAEL estimated from eight ciguatera fish poisoning events in Guadeloupe (French West Indies). Environ. Res. B 143, 100-108. 
Jauffrais, T., Marcaillou, C., Herrenknecht, C., Truquet, P., Séchet, V., Nicolau, E., Tillmann, U., Hess, P., 2012. Azaspiracid accumulation, detoxification and biotransformation in blue mussels (Mytilus edulis) experimentally fed Azadinium spinosum. Toxicon 60, 582-595.

Jauffrais, T., Kilcoyne, J., Herrenknecht, C., Truquet, P., Séchet, V., Miles, C.O., Hess, P., 2013. Dissolved azaspiracids are absorbed and metabolized by blue mussels (Mytilus edulis). Toxicon 65, 81-89.

Klumpp, D.W., Bayne, B.L., Hawkins, A.J.S., 1992. Nutrition of the giant clam Tridacna gigas (L.). I. Contribution of filter-feeding and photosynthates to respiration and growth. J. Exp. Mar. Biol. Ecol. 155, 105-122.

Klumpp, D.W., Griffiths, C.L., 1994. Contributions of phototrophic and heterotrophic nutrition to the metabolic and growth requirements of four species of giant clam (Tridacnidae). Mar. Ecol. Prog. Ser. 115, 103-115.

Laurent, D., Kerbrat, A.S., Darius, T., Girard, E., Golubic, S., Benoit, E., Sauviat, M.P., Chinain, M., Molgo, J., Pauillac, S., 2008. Are cyanobacteria involved in Ciguatera Fish Poisoning-like outbreaks in New Caledonia? Harmful Algae 7, 828-838.

Laurent, D., Kerbrat, A.S., Darius, H.T., Rossi, F., Yeeting, B., Haddad, M., Golubic, S., Pauillac, S., Chinain, M., 2012. Ciguatera Shellfish Poisoning (CSP): a new ecotoxicological phenomenon from cyanobacteria to humans via giant clams. In: Jensen, M.A., Muller D.W. (Eds.), Food Chains: New Research. Nova Science Publishers, New-York, pp. 1-44.

Ledreux, A., Brand, H., Chinain, M., Dechraoui, M.-Y., Ramsdell, J.S., 2014. Dynamics of ciguatoxins from Gambierdiscus polynesiensis in the benthic herbivore Mugil cephalus: trophic transfer implications. Harmful Algae 39, 165-174.

Lewis, R.J., Sellin, M., Street, R., Holmes, M.J., Gillespie, N.C., 1992. Excretion of ciguatoxin from moray eels (Muraenidae) of the central Pacific. In: Tosteson, P.R. (Ed.), Proceedings of the Third International Conference on Ciguatera Fish Poisoning, Puerto Rico, Polysciences, Québec, pp. 131143. 
Lewis, R.J., Yang, A., Jones, A., 2009. Rapid extraction combined with LC-tandem mass spectrometry (CREM-LC/MS/MS) for the determination of ciguatoxins in ciguateric fish flesh. Toxicon 54, 62-66.

Litaker, R.W., Vandersea, M.W., Faust, M.A., Kibler, S.R., Nau, A.W., Holland, W.C., Chinain, M., Holmes, M.J., Tester, P.A., 2010. Global distribution of ciguatera causing dinoflagellates in the genus Gambierdiscus. Toxicon 56, 711-730.

Manger, R.L., Leja, S., Lee, S.Y., Hungerford, J.M., Wekell, M.M., 1993. Tetrazolium based cell bioassay for neurotoxins active on voltage-sensitive sodium channels: semiautomated assay for saxitoxins, brevetoxins, and ciguatoxins. Anal. Biochem. 214, 190-194.

Morton, S.L., Bomber, J.W., Tindall, D.R., 1992. Effect of temperature, salinity and light intensity on the growth and seasonality of toxic dinoflagellates associated with ciguatera. J. Exp. Mar. Biol. Ecol 157, 79-90.

Nicolas, J., Hendriksen, P.J.M., Gerssen, A., Bovee, T.F.H., Rietjens, I.M.C.M., 2014. Marine neurotoxins: state of the art, bottlenecks, and perspectives for mode of action based methods of detection in seafood. Mol. Nutr. Food Res. 58, 87-100.

Parsons, M.L., Settlemier, C.J., Ballauer, J.M., 2011. An examination of the epiphytic nature of Gambierdiscus toxicus, a dinoflagellate involved in ciguatera fish poisoning. Harmful Algae 10, 598-605.

Pauillac, S., Darius, H.T., Chinain, M., 2003. La Ciguatéra : Toxines et détection préventive. Bulletin de l'association des anciens élèves de l'Institut Pasteur 45(176), 148-154.

Pawlowiez, R., Darius, H.T., Cruchet, P., Rossi, F., Caillaud, A., Lauren, D., Chinain, M., 2013. Evaluation of seafood toxicity in the Australes archipelago (French Polynesia), using the neuroblastoma cell-based assay. Food Addit. Contam. A 30(3), 567-586.

Pearson, R.G., Munro, J.L., 1991. Growth, mortality and recruitment rates of giant clams, Tridacna gigas and T. derasa, at Michaelmas Reef, central Great Barrier Reef, Australia. Aust. J. Mar. Freshw. Res. 42, 241-262. 
Reid, R.G.B., Fankboner, P.V., Brand, D.G., 1984. Studies on the physiology of the giant clam Tridacna gigas Linne. I. Feeding and digestion. Comp. Biochem. Physiol. 78, 95-101.

Reverté, L., Soliño, L., Carnicer, O., Diogène, J., Campàs, M., 2014. Alternative methods for the detection of emerging marine toxins: biosensors, biochemical assays and cell-based assays. Mar. Drugs $12,5719-5763$.

Rhodes, L., Towers, N., Briggs, L., Munday R., Adamson J., 2002. Uptake of palytoxin-like compounds by shellfish fed Ostreopsis siamensis (Dinophyceae). N. Z. J. Mar. Freshw. 36, 631-636.

Rolland, J.L., Pelletier, K., Masseret, E., Rieuvilleneuve, F., Savar, V., Santini, A., Amzil, Z., Laabir M., 2012. Paralytic toxins accumulation and tissue expression of a-amylase and lipase genes in the pacific oyster Crassostrea gigas fed with the neurotoxic dinoflagellate Alexandrium catenella. Mar. Drugs 10, 1-16.

Rongo, T., van Woesik, R., 2011. Ciguatera poisoning in Rarotonga, southern Cook Islands. Harmful Algae 10, 345-355.

Skinner, M.P., Brewer, T.D., Johnstone, R., Fleming, L.E., Lewis, R.J., 2011. Ciguatera fish poisoning in the Pacific Islands (1998 to 2008). PLoS Negl. Trop. Dis. 5, e1416.

Sperr, A.E., Doucette, G.J., 1996. Variation in growth rate and ciguatera toxin production among geographically distinct isolates of Gambierdiscus toxicus. In: Yasumoto, T., Oshima, Y., Fukuyo, Y. (Eds.), Harmful and Toxic Algal Blooms. Intergovernmental Oceanographic Commission of UNESCO, Paris, pp. 309-312.

Stewart, I., Eaglesham, G.K., Poole, S., Graham, G., Paulo, C., Wickramasinghe, W., Sadler, R., Shaw, G.R., 2010. Establishing a public health analytical service based on chemical methods for detecting and quantifying Pacific ciguatoxin in fish samples. Toxicon 56, 804-812.

Tosteson, T., Ballantine, D., Durst, H., 1988. Seasonal frequency of ciguatoxic barracuda in southwest Puerto Rico. Toxicon 26, 795-801. 
597 Yasumoto, T., Inoue, A., Ochi, T., Fujimoto, K., Oshima, Y., Fukuyo, Y., Adachi, R., Bagnis, R., 1980.

598 Environmental studies on a toxic dinoflagellate responsible for ciguatera. Bull. Jpn. Soc. Sci. Fish. $599 \quad 46,1397-1404$.

600 Yonge, C.M., 1980. Functional morphology and evolution in the Tridacnidae (Mollusca: Bivalvia: Cardiacea). Rec. Aust. Museum 33, 735-777. 

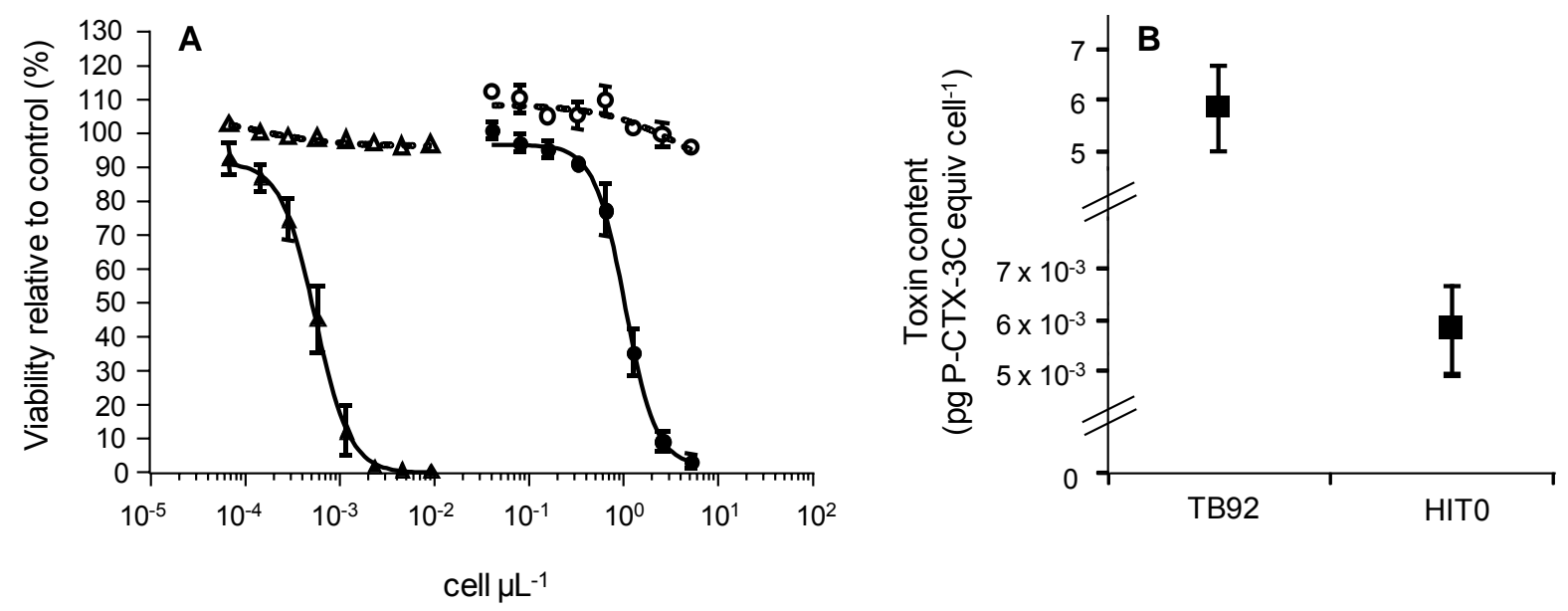

Fig. 1. Toxicity of TB92 (G. polynesiensis) and HITO (G. toxicus) cell batches used for ex situ contamination experiments. (A) Dose-response curves of Neuro-2a cells in $\mathrm{OV}^{-}$(open symbols) and $\mathrm{OV}^{+}$(solid symbols) conditions, when exposed to increasing concentrations of TB92 $(\Delta / \Delta)$ and HITO $(0 / \bullet)$ cells extracts, following the CBA-N2a procedure described in Section 2.4. Sigmoidal curves were observed in $\mathrm{OV}^{+}$conditions, with $\mathrm{EC}_{50}$ values of $(5.39 \pm 0.83) \times 10^{-4}$ and $1.82 \pm 0.81$ cell equiv. $\mu L^{-1}$ for TB2 and HITO, respectively, whereas no cytotoxic effects were observed in OV conditions, responses typical of CTX bioactivity. (B) Toxin contents, 609 which were estimated following the procedure described en Section 2.5 , were $5.83 \pm 0.85$ and $(2.05 \pm 1.16) x$ $61010^{-3} \mathrm{pg} \mathrm{P-CTX-3C} \mathrm{equiv.} \mathrm{cell}{ }^{-1}$ for TB92 and HITO, respectively. HITO showed a toxicity 2,850-fold lower than 611 TB92. Data represent the mean \pm SD of three independent experiments (each run in triplicates) for (A) and (B). 

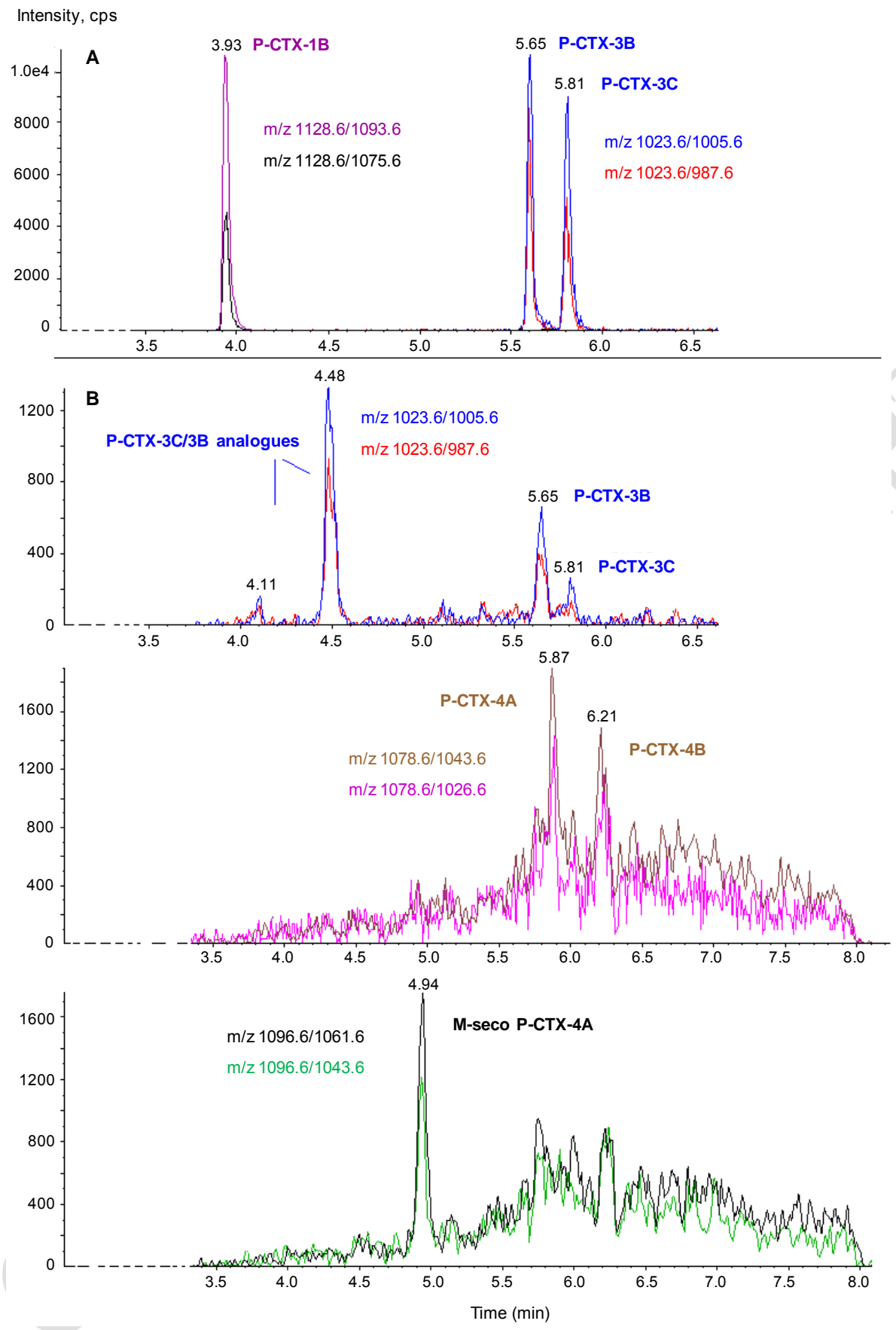

613 Fig. 2. LC-MS/MS chromatograms of (A) P-CTX-1B, P-CTX-3B and P-CTX-3C standards, and (B) TB92 G. 614 polynesiensis cells extract. Chromatograms were acquired following the procedure described in Section 2.6, in 615 positive MRM mode, on $\mathrm{m} / \mathrm{z}$ P-CTXs transitions $[\mathrm{M}+\mathrm{H}]^{+} /\left[\mathrm{M}+\mathrm{H}-2 \mathrm{H}_{2} \mathrm{O}\right]^{+} /\left[\mathrm{M}+\mathrm{H}-3 \mathrm{H}_{2} \mathrm{O}\right]^{+}$or $\left[\mathrm{M}+\mathrm{NH}_{4}\right]^{+} /\left[\mathrm{M}^{+} \mathrm{NH}_{4}-\right.$ $\left.6162 \mathrm{H}_{2} \mathrm{O}\right]^{+} /\left[\mathrm{M}+\mathrm{NH}_{4}-3 \mathrm{H}_{2} \mathrm{O}\right]^{+}$. In TB92 cell extract, P-CTX-3B and P-CTX-3C were formally identified in comparison 617 with standards whereas P-CTX-4A, P-CTX-4B, M-seco-P-CTX-4A and two analogs of P-CTX-3C/3B were 618 tentatively identified based on MRM transitions described in Table 1. 

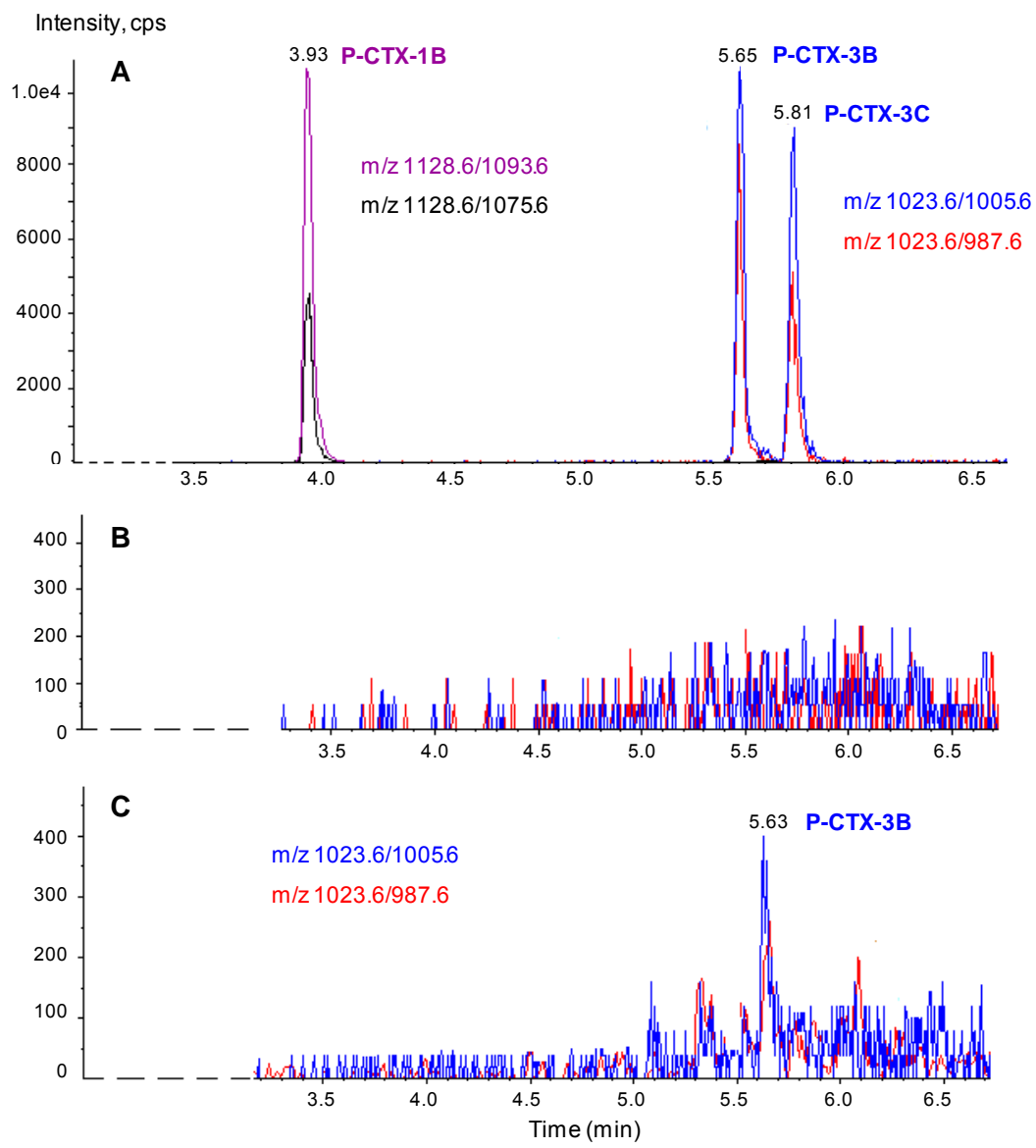

620 Fig. 3. LC-MS/MS chromatograms of (A) P-CTX-1B, P-CTX-3B and P-CTX-3C standards, and extracts of (B) control 621 giant clams and giant clams exposed to HITO cells or (C) giant clams exposed to TB92 cells. Chromatograms 622 were acquired following the procedure described in Section 2.6, in positive MRM mode, on $\mathrm{m} / \mathrm{z}$ P-CTX-3C/B 623 transitions described in Table $1\left([\mathrm{M}+\mathrm{H}]^{+} /\left[\mathrm{M}+\mathrm{H}-2 \mathrm{H}_{2} \mathrm{O}\right]^{+} /\left[\mathrm{M}+\mathrm{H}-3 \mathrm{H}_{2} \mathrm{O}\right]^{+}\right)$. No P-CTXs were detected in control 624 animals or giant clams exposed to HITO cells whereas a single peak corresponding to P-CTX-3B (retention time $625 \mathrm{RT}=5.65 \mathrm{~min}$ ) was detected in the flesh of giant clams exposed to TB92 cells. 


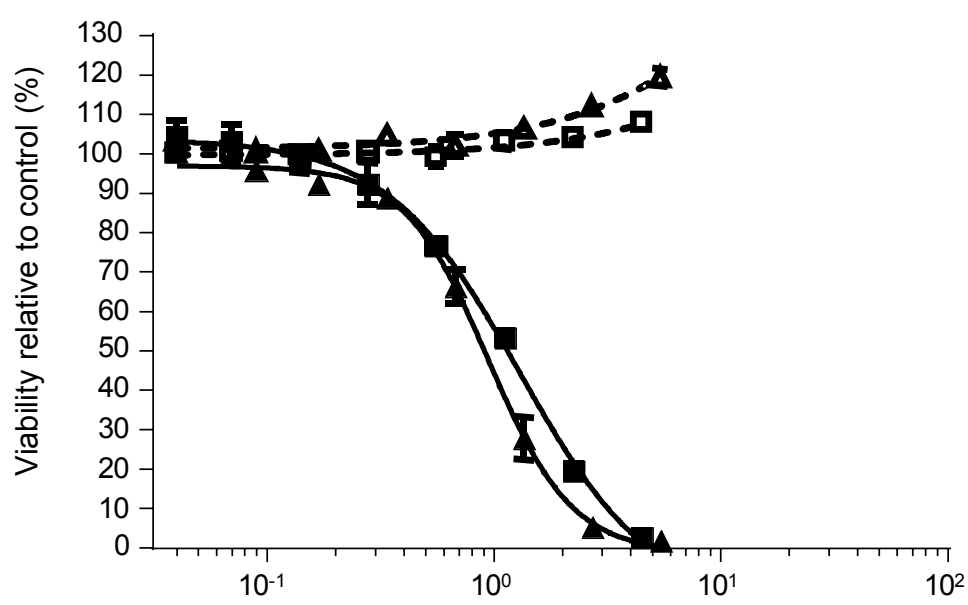

$\mu \mathrm{g}$ wet weight of flesh $\mu \mathrm{L}^{-1}$

627 Fig. 4. Dose-response curves of Neuro-2a cells under OV (open symbols) and $\mathrm{OV}^{+}$(solid symbols) conditions,

628 when exposed to different concentrations of extracts obtained from giant clams exposed to lyzed $(\Delta / \Delta)$ or live

$629(\square / \square)$ TB92 cells following the procedure described in Section 2.4. Responses typical of CTX bioactivity were

630 observed with $\mathrm{EC}_{50}$ values of $1.00 \pm 0.42$ and $1.17 \pm 0.13 \mu \mathrm{g}$ wet weight of flesh equiv. $\mu \mathrm{L}^{-1}$ for giant clams

631 exposed to lyzed or live TB2 cells, respectively. Data represent the mean \pm SD of three independent 632 experiments (each run in triplicates). 


\begin{tabular}{|c|c|c|c|c|c|c|}
\hline \multirow[b]{2}{*}{ Toxin } & \multirow[b]{2}{*}{ Mass } & \multicolumn{2}{|c|}{ MRM transitions $(\mathrm{m} / \mathrm{z})$} & \multicolumn{3}{|c|}{ Retention time (min) } \\
\hline & & $\begin{array}{l}\text { Precursor } \\
\text { ion }\end{array}$ & $\begin{array}{c}\text { Product ions } \\
1 / 2\end{array}$ & $\begin{array}{l}\text { P-CTXs } \\
\text { Standard }\end{array}$ & $\begin{array}{l}\text { TB92 } \\
\text { cells }\end{array}$ & $\begin{array}{l}\text { Giant clams } \\
\text { exposed to } \\
\text { live TB92 } \\
\text { cells }\end{array}$ \\
\hline P-CTX-1B & 1110.6 & $\begin{array}{c}1128.6 \\
{\left[\mathrm{M}+\mathrm{NH}_{4}\right]^{+}}\end{array}$ & $\begin{array}{c}1093.6 / \\
1075.6\end{array}$ & 3.94 & $N D^{*}$ & $N D^{*}$ \\
\hline $\begin{array}{l}\text { P-CTX-2 } \\
\text { P-CTX-3 }\end{array}$ & 1094.6 & $\begin{array}{c}1112.6 \\
{\left[\mathrm{M}+\mathrm{NH}_{4}\right]^{+}}\end{array}$ & $\begin{array}{c}1077.6 / \\
1059.6\end{array}$ & & $\begin{array}{l}N^{*} \\
N D^{*}\end{array}$ & $\begin{array}{l}\mathrm{ND}^{*} \\
\mathrm{ND}^{*}\end{array}$ \\
\hline $\begin{array}{l}\text { P-CTX-3C } \\
\text { P-CTX-3B }\end{array}$ & 1022.6 & $\begin{array}{c}1023.6 \\
{[\mathrm{M}+\mathrm{H}]^{+}}\end{array}$ & $\begin{array}{c}1005.6 / \\
987.6\end{array}$ & $\begin{array}{l}5.80 \\
5.65\end{array}$ & $\begin{array}{l}5.80 \\
5.65\end{array}$ & $\begin{array}{l}N D^{*} \\
5.63\end{array}$ \\
\hline $\begin{array}{l}\text { P-CTX-4A } \\
\text { P-CTX-4B }\end{array}$ & 1060.6 & $\begin{array}{c}1078.6 \\
{[\mathrm{M}+\mathrm{NH} 4]^{+}}\end{array}$ & $\begin{array}{c}1043.6 / \\
1025.6\end{array}$ & & $\begin{array}{l}5.87 \\
6.21\end{array}$ & $\begin{array}{l}\mathrm{ND}^{*} \\
\mathrm{ND}^{*}\end{array}$ \\
\hline M-seco P-CTX-4A & 1078.6 & $\begin{array}{c}1096.6 \\
{\left[\mathrm{M}+\mathrm{NH}_{4}\right]^{+}}\end{array}$ & $\begin{array}{c}1061.6 / \\
1043.6\end{array}$ & & 4.94 & $N D^{*}$ \\
\hline M-seco P-CTX-3C & 1040.6 & $\begin{array}{c}1058.6 \\
{\left[\mathrm{M}+\mathrm{NH}_{4}\right]^{+}}\end{array}$ & $\begin{array}{c}1023.6 / \\
1005.6\end{array}$ & & $N D^{*}$ & $N D^{*}$ \\
\hline 51-OH Р-CTX-3C & 1038.6 & $\begin{array}{l}1039.6 \\
{[\mathrm{M}+\mathrm{H}]^{+}}\end{array}$ & $\begin{array}{c}1021.6 / \\
1003.6\end{array}$ & & $N D^{*}$ & $N D^{*}$ \\
\hline 2,3 diOH P-CTX-3C & 1055.6 & $\begin{array}{c}1056.6 \\
{[\mathrm{M}+\mathrm{H}]^{+}}\end{array}$ & $\begin{array}{c}1038.6 / \\
1021.6\end{array}$ & & $N D^{*}$ & $N D^{*}$ \\
\hline
\end{tabular}

634 Table 1. LC-MS/MS analyses of P-CTXs standards and extracts of TB92 cells and giant clams exposed to

635 TB92. Mass spectrometry detection was performed in positive mode using MRM transitions as described in

636 Section 2.6. The pseudomolecular ions $\left[\mathrm{M}+\mathrm{NH}_{4}\right]^{+}$and $[\mathrm{M}+\mathrm{H}]^{+}$were selected as precursor ions. The ions

637 resulting in the successive losses of two and three water molecules were selected as product ions 1 and 2 ,

638 respectively. *ND: no detected. 


\begin{tabular}{|c|c|c|c|c|c|c|}
\hline $\begin{array}{l}\text { Condition } \\
\text { of } \\
\text { exposure }\end{array}$ & Strain & $\begin{array}{c}\text { Giant } \\
\text { clams per } \\
\text { tank }\end{array}$ & $\begin{array}{c}\text { Giant } \\
\text { clams total } \\
\text { wet weigh } \\
\text { (g) }\end{array}$ & $\begin{array}{c}\mathrm{EC}_{50} \pm \mathrm{SD} \\
(\mu \mathrm{g} \text { wet } \\
\text { weight of } \\
\left.\text { flesh } \mu \mathrm{L}^{-1}\right)\end{array}$ & $\begin{array}{c}\text { Toxin content } \\
\pm \text { SD (ng P- } \\
\text { CTX-3C equiv. } \\
g^{-1} \text { wet weight } \\
\text { of flesh) }\end{array}$ & $\begin{array}{l}\text { Accumulation } \\
\text { of equiv. } \\
\text { P-CTX-3C per } \\
\text { tank } \pm \text { SD (\%) }\end{array}$ \\
\hline \multirow{6}{*}{ Lyzed cells } & control & 3 & 213 & $N D^{*}$ & $\mathrm{ND}^{*}$ & $N^{*}$ \\
\hline & HITO & 3 & 180 & $N D^{*}$ & $N D^{*}$ & $N D^{*}$ \\
\hline & TB92, tank 1 & 3 & 176 & $0.83 \pm 0.06$ & $3.74 . \pm 0.26$ & $3.82 \pm 0.27$ \\
\hline & TB92, tank 2 & 3 & 159 & $0.68 \pm 0.07$ & $4.96 \pm 0.58$ & $5.06 \pm 0.59$ \\
\hline & TB92, tank 3 & 3 & 137 & $1.54 \pm 0.07$ & $2.02 \pm 0.10$ & $2.06 \pm 0.10$ \\
\hline & $\begin{array}{l}\text { TB92, average } \\
\text { of tanks } 1-3\end{array}$ & 9 & 157 & $1.00 \pm 0.42$ & $3.58 \pm 1.32$ & $3.65 \pm 1.34$ \\
\hline \multirow{6}{*}{ Live cells } & control & 2 & 95 & $N D^{*}$ & $N^{*}$ & $N D^{*}$ \\
\hline & HITO & 3 & 172 & $\mathrm{ND}^{*}$ & $N D^{*}$ & $N D^{*}$ \\
\hline & TB92, tank 1 & 3 & 170 & $0.84 \pm 0.26$ & $3.94 \pm 1.21$ & 3. $89 \pm 1.19$ \\
\hline & TB92, tank 2 & 3 & 224 & $1.24 \pm 0.15$ & $2.48 \pm 0.29$ & $2.88 \pm 0.52$ \\
\hline & TB92, tank 3 & 3 & 197 & $1.39 \pm 0.39$ & $2.34 \pm 0.54$ & $2.47 \pm 0.48$ \\
\hline & $\begin{array}{l}\text { TB92, average } \\
\text { of tanks } 1-3\end{array}$ & & 197 & $1.17 \pm 0.13$ & $2.92 \pm 1.03$ & $3.06 \pm 0.96$ \\
\hline
\end{tabular}

640 Table 2. Estimation of the toxin contents and percentages of toxin accumulation for giant clams exposed to

641 lyzed or live Gambierdiscus sp. cells, using CBA-N2a. HIT0: toxicity results of giant clams contaminated with G.

642 toxicus strain; TB92: toxicity results of giant clams contaminated with G. polynesiensis strain. *ND: no

643 detectable. For exposures to lyzed or live TB92 cells, bold values represent the mean of the three replicates

644 (tanks 1, 2 and 3). Each data represents the mean \pm SD of three independent experiments (each run in

645 triplicates). 